\section{Northern blot}

\author{
A. M. Gressner ${ }^{1}$ und O. A. Gressner ${ }^{2}$ \\ ${ }^{1}$ Labor Dr. Wisplinghoff Berlin, Berlin, Deutschland \\ ${ }^{2}$ Labor Dr. Wisplinghoff Köln, Köln, Deutschland
}

\section{Synonym(e) RNA blot}

Englischer Begriff northern blotting

Definition Der Northern blot ist eine Methode zur elektrophoretischen Auftrennung von RNA mit nachfolgender elektrophoretischer Übertragung des kompletten Trennmusters auf eine Trägerfolie, auf der es fixiert und identifiziert wird.

Physikalisch-chemisches Prinzip In einem ersten Schritt erfolgt die agargelelektrophoretische Trennung des RNAGemisches nach ihrer Molekülgröße unter vollständig denaturierenden Bedingungen. Dazu kann die Auftrennung in Glyoxal-, Formaldehyd-, Harnstoffgelen oder unter alkalischen Bedingungen erfolgen. Im zweiten Schritt erfolgt der Transfer der aufgetrennten RNA-Fragmente auf eine Nylonoder Nitrocellulosemembran, auf der sie im dritten Schritt durch Hitzeeinwirkung oder UV-Bestrahlung fixiert und danach identifiziert werden. Mit markierten Gensonden, das sind radioaktiv- oder fluoreszenzmarkierte, einzelsträngige DNA-, RNA-Moleküle oder synthetische Oligonukleotide mit einer zur Ziel-RNA komplementären, hybridisierenden Basensequenz, können die RNA-Fragmente identifiziert werden. Mitgeführte RNA-Molekulargewichtsmarker erlauben die Größenbestimmung der aufgetrennten Fragmente.
Einsatzgebiete Die Methode dient primär dem qualitative und quantitativen Nachweis spezifischer Genexpressionen und somit der Transkriptionsstärke eines Gens.

Untersuchungsmaterial Isolierte RNA, mRNA aus allen humanen und tierischen Geweben und Zellen.

Instrumentalisierung Agargelelektrophorese ( $\triangleright$ Elektrophorese), Blotting-Apparatur, - Autoradiographie.

Spezifität - Sensitivität Hoch bei optimaler Durchführung.

Fehlermöglichkeit Bei inkorrekter Durchführung grundsätzlich in allen Teilschritten gegeben.

Praktikabilität - Automatisierung - Kosten Es handelt sich im Allgemeinen um ein molekularbiologisches Standardverfahren, das nicht automatisiert ist.

Bewertung Es handelt sich um eine Methode mit breitem Anwendungsbereich in Forschung und erweiterter, differenzierter Labordiagnostik.

\section{Literatur}

Alwin JC, Kemp DJ, Stark GR (1977) Method for detection of specific RNAs in agarose gel by transfer to diazobenyloxymethyl-paper and hybridization with DNA probes. Proc Nat Acad Sci USA 74: $5350-5354$ 